\title{
PENGGUNAAN TEKNIK PCR DAN RFLP UNTUK DETEKSI DAN ANALISIS KERAGAMAN VIRUS GEMINI PADA TANAMAN TOMAT YANG BERASAL DARI BERBAGAI DAERAH DI JAWA BARAT DAN LAMPUNG
}

\author{
Sudiono $^{1}$, Sri Hendrastuti Hidayat ${ }^{2}$, Rusmilah Suseno ${ }^{2}$, dan Soemartono Sosromarsono ${ }^{2}$
}

\begin{abstract}
The Technique of PCR and RFLP to detection and analysis geminivirus diversity on tomato from growing areas in West Java and Lampung. Geminivirus infection has been reported on various important crops, among others on tomato. Infected plant were collected from six tomato growing areas in West Java (Bandung, Segunung, Darmaga, Ciloto, Cibeuying, and Cisaat) and Lampung (Bandar Lampung). Polymerase chain reaction method using universal primers for geminiviruses were successfully amplified a $1.5 \mathrm{~kb}$ DNA fragment from diseased plants from Bandung, Cisaat, Ciloto and Cibeunying. Comparative model enzyme restriction showed that sample from Bandung, Cisaat, Ciloto are probably strains of the same virus.
\end{abstract}

Key words: geminivirus, polymerase chain reaction, restriction fragment length polymorphism

\section{PENDAHULUAN}

Tomat (Lycopersicum esculentum Mill.) merupakan salah satu komoditas sayuran penting karena kandungan gizinya yaitu protein, karbohidrat, lemak, vitamin dan mineral. Permintaan tomat cenderung meningkat dari waktu ke waktu sejalan dengan meningkatnya rata-rata konsumsi tomat di beberapa negera dan meningkatnya jumlah penduduk.

Villareal (1980) memperkirakan rata-rata konsumsi tomat di negera-negera tropika pada tahun 1965 sebesar 3,43 kg/kapita/tahun meningkat menjadi $6,13 \mathrm{~kg} / \mathrm{kapita} / \mathrm{tahun}$ pada tahun 1977 . Sedangkan menurut prediksi FAO kebutuhan sayuran dan buahbuahan di Indonesia pada tahun 2000 adalah sebesar $82,35 \mathrm{~kg} / \mathrm{kapita} / \mathrm{tahun}$. Di antara lebih kurang 400 jenis sayuran dan buah-buahan yang ada di Indonesia, tomat merupakan salah satu komoditas yang memberikan sumbangan keragaman gizi dan dapat menjadi sumber devisa yang menjanjikan. Permintaan terhadap komoditi tomat diperkirakan akan terus meningkat (Rukmana, 1994).

Epidemi penyakit virus merupakan kendala dalam meningkatkan produksi tomat di dunia termasuk di Indonesia. Jones et al. (1991) melaporkan lebih dari 30 virus dapat menyerang tanaman tomat dan mengakibatkan kerugian yang cukup besar. Sedangkan di Indonesia ada 5 virus yang telah dilaporkan menyerang tanaman tomat yaitu: tobacco mosaic virus (TMV), cucumber mosaic virus (CMV), potato virus $Y$ (PVY), potato virus $X$
(PVX) dan tomato ringspot virus (TRSV) (Duriat, 1996) dan gemini virus (Sugiarman dan Hidayat, 2000).

Virus gemini telah dilaporkan tersebar di beberapa negera, yaitu Israel, Brasil, Venezuela, Kuba, Portugal, Tanzania, Thailand, USA, Afrika, Mexico, dan Karibia (Gusman et al. 1997, Ramos et al. 1996, Louro et al. 1996, Chiang et al. 1997, Honda et al. 1983, Zerbirin et al. 1996, Wisler et al. 1996, Polston 1996, Pacheco et al., 1996). Kerugian akibat serangan virus gemini juga telah banyak dilaporkan. African cassava mosaic virus misalnya menyebabkan kerugian hasil sebesar 70\% di Afrika. Di Libanon ubikayu dan Jordania kerugian akibat virus gemini pada tanaman tomat mencapai 50-70\% (Bock et al., 1977). Virus gemini di Indonesia telah dilaporkan menyerang tanaman tembakau (Trisusilowati, 1989), tanaman cabai (Rusli, 2000), dan tanaman tomat (Sugiarman \& Hidayat, 2000).

Kerugian akibat serangan virus gemini di masa yang akan datang di suatu wilayah diharapkan dapat dikendalikan melalui deteksi virus secara dini yang merupakan salah satu strategi pengendalian preventif yang baik. Hal tersebut dapat terlaksana bila telah tersedia metode deteksi yang akurat dan cepat. Salah satu teknik molekuler yang potensial untuk dikembangkan sebagai alat deteksi dini adalah teknik polymerase chain reaction (PCR). Keragaman biologi gemini virus juga dapat untuk mengetahui penyebaan strain gemini virus di beberapa area di Indonesia, oleh sebab itu penggunaan teknik

\footnotetext{
${ }^{1}$ Dosen Jurusan Proteksi Tanaman Fakultas Pertanian Universitas Lampung, Jl. Soemantri Brodjonegoro, 1 Bandar Lampung, 35145.

2 Dosen Departemen Hama dan Penyakit Tumbuhan, Fakultas Pertanian Institut Pertanian Bogor, Jl Kamper Kampus IPB Darmaga, Bogor, 16680.
} 
restriction fragment length polymorphism (RFLP) diperoleh untuk mengidentifikasi penyebaran strain gemini virus.

Penelitian ini bertujuan untuk melakukan deteksi virus gemini pada tanaman tomat melalui kegiatan-kegiatan: Penggunaan teknik PCR untuk mendeteksi keberadaan virus gemini dan penggunaan teknik RFLP untuk melakukan analisis keragaman sampel.

\section{METODE PENELITIAN}

Penelitian dilaksanakan mulai bulan November 1999 sampai bulan Desember 2000 di Laboratorium Virologi Tumbuhan dan Rumah Kaca Jurusan Hama dan Penyakit Tumbuhan Fakultas Pertanian Institut Pertanian Bogor.

Penelitian meliputi dua kegiatan yaitu deteksi virus pada tanaman yang bergejala dengan teknik PCR, dan diferensiasi sampel dengan teknik RFLP.

\section{Deteksi Virus dengan Teknik PCR (Polymerase Chain Reaction)}

\section{a. Ekstraksi DNA}

Ekstraksi DNA dari sampel jaringan tanaman dilakukan dengan mengikuti prosedur Dellaporta (1983). Daun tanaman sakit (0,5-1 g) dimasukkan ke dalam tabung eppendorf kemudian ditambahkan 500 $\mu$ bufer (100 mM Tris pH 8, 50 mM EDTA, $500 \mathrm{mM}$ $\mathrm{NaCl}$ ) dan $\beta$-mercaptoethanol (5\%). Setelah daun digerus ditambahkan $500 \mu \mathrm{l}$ phenol chloroform isoamylalcohol (PCI) (25:24:1) dan divorteks supaya tercampur baik dan disentrifugasi dengan kecepatan $12.000 \mathrm{rpm}$ selama 5 menit pada suhu $25 \mathrm{C}$ dan diambil supernatannya. Ke dalam supernatan yang diperoleh ditambahkan $33 \mu$ l SDS 20\% dan kemudian divorteks. Dan kemudian diinkubasi pada suhu 65 C selama 10 menit ditambahkan $160 \mu \mathrm{l} 5 \mathrm{M}$ KoAC, divorteks, disentrifugasi 12.000 rpm 5 menit suhu 25 C, dan diambil supernatannya. Langkah terakhir ini diulang sekali lagi. Pada hasil supernatan yang kedua ditambahkan 0,5 volume isopropanol, divorteks dan disentrifugasi $12.000 \mathrm{rpm} 5$ menit pada suhu $25 \mathrm{C}$. Pada tahap ini suspensi dibuang, sedangkan pelet dicuci dengan menambahkan $500 \mu \mathrm{l} 70 \%$ etanol, disentrifugasi $12.000 \mathrm{rpm} 5$ menit pada suhu $25 \mathrm{C}$, dan dibuang supernatannya. Pelet yang diperoleh diresuspensi dengan $300 \mu \mathrm{l} \mathrm{H}_{2} \mathrm{O}$. Selanjutnya dilakukan ekstraksi dengan menambahkan $300 \mu \mathrm{l}$ PCI, divorteks, disentrifugasi $12.000 \mathrm{rpm} 5$ menit denan suhu 25 C. Lapisan atas dipindahkan ke tabung baru dan ditambahkan 0,1 volume $\mathrm{NaOAC}$ dan 1 volume etanol absolut, diinkubasi pada -20 C selama 20 menit dan disentrifugasi. Pelet yang diperoleh dicuci dua kali dengan etanol 70\% masing-masing sebanyak 500 $\mu \mathrm{l}$. Pelet yang dihasilkan dikeringkan (kering udara dan vakum) kemudian diresuspensi dengan $30 \mu \mathrm{l} \mathrm{H}_{2} \mathrm{O}$ dan suspensi tersebut disimpan sebelum digunakan lebih lanjut.

\section{b. Amplifikasi DNA}

DNA hasil ekstraksi diamplifikasi dengan teknik PCR mengikuti prosedur Rojas et al. (1993), dengan primer universal virus gemini (PAL1v 1978 dan PAL1c 715). Primer itu akan mengamplifikasi bagian gen protein replikasi dan protein selubung dengan ukuran fragmen DNA berukuran $\approx 1,6 \mathrm{~kb}$. Reaksi PCR (total volume $25 \mu \mathrm{l}$ ) menggunakan Ready To Go PCR Beads (Amersham Pharmacia Biotech) terdiri atas $10 \mu \mathrm{l}$ sampel DNA, 1 bead yang mengandung $200 \mu \mathrm{M}$ dNTP, 1.5 unit Taq DNA polimerase, $10 \mathrm{mM}$ Tris $\mathrm{HCl}, 50 \mathrm{mM} \mathrm{KCl}, 1.5 \mathrm{mM}$ $\mathrm{MgCl}_{2}$ dan primer PAL1v 1978 dan PAL1c 715 masing-masing sebanyak $1 \mu \mathrm{M}$. Ke dalam tabungtabung PCR diberi 1 tetes minyak mineral untuk mencegah penguapan. Tabung-tabung tersebut ditempatkan pada mesin PCR (thermal cycler) pada suhu $92 \mathrm{C}$ selama 1-5 menit untuk deanturasi awal. Amplifikasi dengan PCR dilakukan sebanyak 35 siklus dengan tahapan sebagai berikut: tahap I suhu 94 C selama 2 menit, tahap II suhu 55 C selama 2 menit, tahap suhu III $72 \mathrm{C}$ selama 3 menit. Akhir daur dipertahankan pada suhu $4 \mathrm{C}$ sampai tabung diambil. Hasil PCR disimpan di dalam freezer untuk digunakan lebih lanjut.

\section{c. Visualisasi DNA}

DNA virus gemini hasil amplifikasi dianalisis melalui elektroforesis menggunakan jel agarose $1 \%$ (dalam TBE 0,5X) yang mengandung ethidium bromide. Untuk pengukuran DNA digunakan marker $1 \mathrm{~kb}$ ladder. Sampel disiapkan dengan mencampurkan $8 \mu$ l DNA dan loading buffer sebanyak $2 \mu$ l. Selanjutnya masing-masing sampel diisikan dalam sumuran jel dengan pipet mikro. Elektroforesis dilakukan dengan tegangan 75 V DC selama 90 menit. Hasil eletroforesis tersebut dilihat dengan transilluminator UV dan dipotret. 


\section{Analisis Keragaman Virus Gemini dengan Teknik} RFLP

Analisis hasil PCR dilakukan melalui pemotongan fragmen DNA dengan empat macam enzim restriksi (endonuklease) yaitu: EcoRI, PstI, Hind III, dan BamHI. Sampel DNA sebanyak $5 \mu$ dari hasil duplikasi DNA gemini virus dipotong dengan enzim restriksi. Campuran reaksi terdiri atas enzim restriksi $2 \mu \mathrm{l}$, bufer $1 \mu \mathrm{l}$ dan akuades $7 \mu \mathrm{l}$, dilanjutkan dengan inkubasi pada suhu $37 \mathrm{C}$ selama 68 jam. Hasil pemotongan divisualisasi dengan elektroforesis agarose $1 \%$. Perbedaan antar sampel ditunjukkan dengan adanya variasi ukuran pita DNA.

\section{HASIL DAN PEMBAHASAN}

\section{Deteksi Virus Gemini dengan Teknik PCR}

Infeksi virus gemini pada tanamn tomat berhasil terdeteksi dari tanaman asal Bandung, Cisaat, Ciloto dan Cibeunying (Gambar 1).

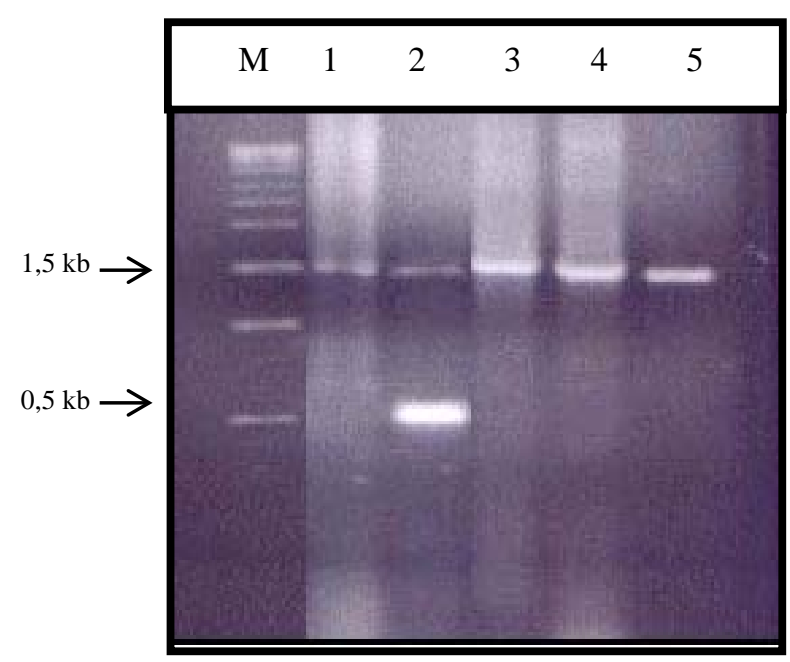

Gambar 1. Hasil PCR terhadap DNA virus gemini dari beberapa sampel dengan primer universal PAL1v 1978 dan PAL1c 715. $\mathrm{M}=$ Marker $1 \mathrm{~kb}, 1=$ Sampel Bandung, 2=Sampel Cisaat, 3= Sampel Ciloto, 4= Sampel Cibeunying, 5= Bean Golden Mosaic Virus Brazil (DNA kloning)
Pita DNA berukuran $1.5 \mathrm{~kb}$ tampak pada gel agarose (1\%) setelah proses amplifikasi dengan teknik PCR menggunakan primer universal virus gemini PAL1v 1978 dan PAL1c 715. Fragmen DNA dengan ukuran tersebut sesuai dengan ukuran yang diharapkan dengan primer tersebut (Rojas et al. 1993).

\section{Analisis Keragaman Virus Gemini dengan Teknik RFLP}

Analisis RFLP DNA virus gemini dari Bandung, Cisaat, Ciloto dan Cibeunying dengan enzim EcoRI, BamHI, PstI, dan Hind III, diharapkan menghasilkan pola restriksi DNA yang dapat digunakan sebagai dasar untuk mengetahui adanya perbedaan antar sampel (Gambar 2). Penggunaan enzim EcoRI menghasilkan tiga pita masing-masing berukuran sekitar 400, 500 dan 600 bp pada sampel Bandung, Cisaat dan Cibeunying. Sedangkan sampel Ciloto tidak terpotong oleh enzim tersebut. Demikian pula pola pemotongan dengan enzim BamHI dan Hind III menghasilkan pita dengan ukuran yang sama sekitar 600 dan 900 bp pada ketiga sampel tersebut, tetapi sampel Ciloto tidak terpotong. Pada enzim PstI tidak ada DNA yang terpotong pada semua sampel. Dengan demikian virus gemini sampel Bandung, Cisaat, Cibeunying memiliki pola pemotongan DNA yang sama sedangkan virus gemini sampel Ciloto memiliki pola yang berbeda dari ketiga sampel terdahulu.

Keberhasilan teknik PCR mendeteksi virus gemini pada tanaman dan serangga vektor menunjukkan bahwa teknik tersebut dapat digunakan sebagai bagian dari strategi pengendalian penyakit terutama untuk digunakan dalam penentuan peringatan dini di lapangan.

Primer PAL1v 1978 dan PAL1c 715 merupkan primer universal virus gemini yang dirancang berdasarkan sekuen DNA beberapa virus gemini (Rojas et al. 1993). Dengan pasangan primer yang sama, Rusli (2000) berhasil mendeteksi virus gemini dari tanaman cabai. Wang et al. (1996) melakukan pengujian virus gemini dengan primer PAL1v1978 dan PAR 1c496 dan memperoleh fragmen DNA pada ukuran 1,1 kb. Chiang et al. (1997) dengan primer PAC1v1978 dan PAV1c 715 mendeteksi virus gemini pada kutukebul yang diakuisisikan pada tanaman tomat sakit dan berhasil memperoleh fragmen DNA ukuran 1,5 kb. Kato et al. (1998) mendeteksi virus TYLCV dengan teknik PCR dengan menggunakan primer A-1 dengan hasil fragmen pada berukuran 1,3 kb. 


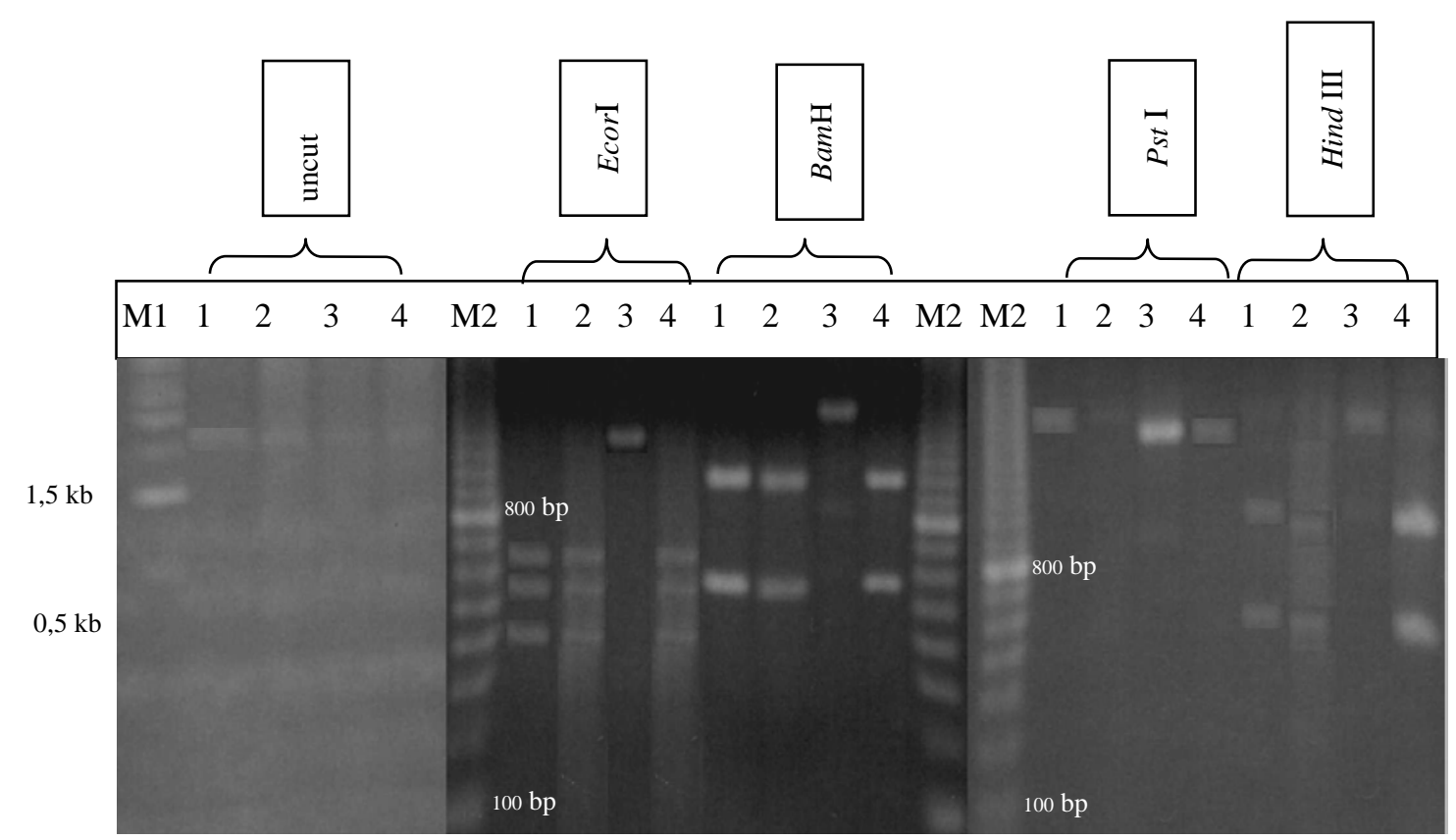

Gambar 2. Pemotongan fragmen DNA virus gemini hasil amplifikasi PCR dengan beberapa enzim restriksi (M1= Marker $1 \mathrm{~kb}, 1=$ sampel Bandung, 2=sampel Cisaat, 3=sampel Ciloto,4= sampel Cibeunying, M2= Marker 100 bp)

Teknik PCR dapat digunakan untuk mendeteksi virus gemini pada tanaman tomat. Selain itu teknik tersebut juga dapat untuk mendeteksi virus gemini pada vektor seperti yang dilaporkan oleh Aidawati (2000) yang melakukan deteksi virus gemini pada $B$. tabaci.

Analisis pola pemotongan enzim restriksi menunjukkan kemungkinan adanya virus gemini yang berbeda strainnya. Pola pita hasil pemotongan enzim restriksi virus gemini sampel Bandung, Cisaat dan Cibeunying berbeda dengan virus gemini sampel Ciloto. Teknik RFLP digunakan untuk mengetahui perbedaan sampel dengan cara melakukan pemotongan terhadap DNA hasil amplifikasi PCR. Hidayat et al. (1999) yang melakukan pemotongan virus gemini asal cabai dengan beberapa enzim melaporkan bahwa virus gemini asal cabai Segunung berbeda dengan virus cabai Cugenang dan Baranangsiang.

Untuk lebih meyakinkan perbedaan antar sampel perlu pengujian dengan analisis sikuen DNA. Bila hubungan antar sampel virus telah diketahui, maka dapat dilakukan penelitian lebih lanjut seperti pengembangan tanaman tahan.

\section{SIMPULAN}

Berdasarkan uji PCR dengan primer universal (PAL1V 1978 dan PAR1c 715), tanaman tomat asal Bandung, Cisaat, Ciloto dan Cibeunying terbukti terinfeksi virus gemini. Teknik RFLP dapat mengetahui keragaman virus gemini sampel Bandung, Cisaat, Cibeunying memiliki pola pemotongan enzim yang sama sedangkan virus gemini sampel Ciloto memiliki pola pemotongan yang berbeda dari ketiga sampel lainnya.

\section{DAFTAR PUSTAKA}

Aidawati, N. 2000. Penularan virus krupuk tembakau dengan Bemisia tabaci Gennadius (Homoptera:Aleyrodidae). Tesis. Pascasarjana. Institut Pertanian Bogor. Bogor.

Bock, K.R., E.J. Gutric, G. Meredeth \& H. Baker. 1977. RNA and protein component of Maize 
Streak Virus and Cassava Leaf Virus. Ann. Appl. Biol. 85:305-308.

Chiang, B.T., M.K. Nakhla, D.P. Maxwel, W. Schoenfelder \& S.K. Green. 1997. A new geminiviruses association with a leaf curl disease of tomato in Tanzania. Plant Disease 81:1111 (abstract).

Dellaporta, S.L., J. Wood \& J.B. Hicks. 1983. A plant DNA minipreparation: Version II. Plant. Mol. Rep. 1:1:19-21.

Dhar, A.K. \& R.P. Singh. 1996. Geminiviruses In. Sing, R.P., U.S. Sing \& K. Kohmato. Pathogenesis and Host Specificity in Plant Diseases: Histopahological, biochemical, genetic and molecular bases: Volume III Viruses and Viroid. pp 289-309.

Duriat, A.S. 1996 Pencegahan penyakit virus pada tanaman tomat. Prosiding Seminar Ilmiah Nasional Komoditas Sayuran hal 575-581.

Gusman, P.C., C.R. Arrendando, D. Emndj, R.J. Portillo, Heinz \& R.L. Giberstson. 1997. Partial characterization of two whiteflies transmitted geminiviruses infecting tomatoes in Venezuela. Plant Disease. 81:312 (Abstract).

Hidayat, S.H., Rusli, E.S. \& Aidawati, N. 1999. Penggunaan primer universal dalam PCR untuk mendeteksi virus gemini pada cabe. Prosiding Kongres Nasional XV dan Seminar Ilmiah PFI Purwokerto 16-18 September 1999. Hal 355359

Honda Y., M. Iwahi, Y. Saito, P. Thongmeearkom, K. Kittisak \& N. Deema. 1983. Mechanical transmission, Purification and some properties of whitefly borne Mungbean Yellow Mosaic Virus in Thailand. Plant Disease. 67:801-844.

Jones, J.B., R.E. Stall, \& T.A. Zitter. 1991. Compendium of Tomatoes Diseases. APS Press. hal:145-160

Kato K., M. Onuki, S. Fuji \& K.Hanada. 1998. The first occurrence of tomato yellow leaf curl virus in tomato (Lycopersicon esculentum Mill). Ann. Phytopathol.Soc. Jpn. 64:552-559.
Louro, D., E. Noris, F.Verralt \& G.P. Accoto. 1996. First report Tomato Leaf Curl Virus in Portugal. Plant Disease, 80: 1079 (Abstract),

Polston, J.E. 1996. Tomato geminiviruses in the Caribben: their identification and management. Phytopathol. 86:S71 (Abstract).

Pacheco, I.T., J.A.G. Tiznado, \& J.K. Brown. 1996. Detection and distribution of geminiviruses in Mexico and Southern United States, Phytopathol. 86:1186-1192

Ramos, P.L., O. Guerra, V. Dorestes \& N. Ramirez. 1996. Detection of TYLCV in Cuba, Plant Disease 80:1208 (abstract).

Rojas, M.R., R.L. Gilbertson, D.R. Russel, \& D.P. Maxwel. 1993. Use of degenerate primers in the polymerase chain reaction to detect whitefly transmitted geminiviruses. Plant Disease. 71:340-347.

Rukmana, R. 1994. Tomat \& Chery. Kanisius.

Rusli, E.S. 2000. Deteksi dan karakterisasi virus gemini asal cabai rawit (Capsicum frustescens L.). Tesis. Pascasarjana Institut Pertanian Bogor. Bogor. 42 halaman.

Sugiarman, \& S.H. Hidayat. 2000. Evaluasi ketahanan beberapa kultivar tomat (Lycopericum esculentum Mill) terhadap virus gemini, Jurnal Biosains Hayati. 3:113-116.

Trisusilowati, E.B. 1989. Studi sifat virus penyebab penyakit krupuk pada tanaman tembakau (Nicotiana tabacum L.). Disertasi. Pascasarjana IPB. Bogor.

Villareal, R.L. 1980. Tomato in The Tropics. Westview Press, Boulder. Colorado.

Wang, H.L, R..L. Gilbertson \& W. J. Lucas. 1996. Spatial and temporal distribution of bean dwarf mosaic virus in $P$. vulgaris and $N$. benthamiana. Phytopathol. 86:1204-1213.

Zerbirin, F.M., E.M. Zambolin, I.V. Cerrijo \& R.L. Gilberstson. 1996. A new bipartite geminiviruses infecting tomatoes in Minas Gerais State, Brazil, Phytopathol. 86:S1 (Abstract). 